\title{
A Justiça Militar e a implantação da ordem republicana no Brasil
}

\author{
Renato Luis do Couto Neto e Lemos \\ Universidade Federal do Rio de Janeiro \\ Rio de Janeiro, RJ, Brasil \\ renato.lemos@historia.ufrj.br
}

\section{RESUMO}

Este artigo discute a relação entre a Justiça Militar brasileira e o processo político como um elemento da constituição da ordem republicana após 1889. É analisada a continuidade das instituiçóes monárquicas na área da justiça castrense. Apontam-se, ainda, os mecanismos doutrinários e organizacionais que viabilizaram a instrumentalização política da Justiça Militar durante os governos de Deodoro da Fonseca e Floriano Peixoto.

Palavras-chave: Justiça Militar; justiça de exceção; direito militar; implantação da República; militares e política.

\begin{abstract}
This article discusses the relationship between the Brazilian Military Justice and the political process as constitutive element of the Republican order after 1889. It analyzes the continuity of monarchical institutions in the Military Justice. It also points out doctrinal and organizational mechanisms that enabled the political exploitation of the Military Justice under Deodoro da Fonseca's and Floriano Peixoto's administrations.
\end{abstract}

Keywords: Military Justice; justice of exception; military law; establishment of the Republic; military and politics. 
A tradição dos oprimidos nos ensina que o "estado de exceção" em que vivemos é a regra. Precisamos chegar a um conceito de história que corresponda a isso'.

A implantação da ordem republicana no Brasil deu-se no contexto de uma crise de hegemonia que marcou as duas últimas décadas do século XIX. Esgotava-se o projeto de sociedade implantado com base nos interesses materiais e na visão de mundo das classes ligadas à agricultura escravista e exportadora e de seus aliados no comércio, finanças e burocracia, e sintetizado no Estado monárquico centralizado². Não resistia à ascensão de uma fração de classe mais dinâmica, identificada com a cafeicultura do Oeste paulista, nem ao desgaste político gerado pela extinçáo da escravatura sem indenização ${ }^{3}$.

A via conservadora de superação das estruturas monárquicas encontrou em segmentos das Forças Armadas, em especial do Exército, seu "partido político", mais efetivo do que poderia ser o Partido Republicano no cumprimento da tarefa histórica de controlar o processo de implantaçáo e consolidaçáo de uma nova ordem ${ }^{4}$. Em um quadro nacional de rupturas articuladas com permanências estratégicas, o novo tipo de ação militar constituiu uma importante mudança em relação à fase monárquica, que não conheceu golpes militares nem a participação institucional castrense no poder. Se entendida como um importante episódio da modernização capitalista tardia da sociedade brasileira, a implantaçáo da ordem republicana surgirá concentrada na construção de um novo formato de Estado, capaz de redefinir a unidade nacional sem violentar na raiz a força dos focos de poder regionalizados.

$\mathrm{Na}$ falta de um partido político de âmbito nacional ou de instituições que fizessem a mediação entre os diversos setores postulantes à direção política do país, as Forças Armadas cumpriram esse papel. Executoras da ação que derrubou a monarquia em 15 de novembro de 1889, elas emergiram como "árbitro" dos conflitos políticos que marcaram os primeiros cinco anos da República ${ }^{5}$. Entretanto, como a conjuntura política apresentava elementos que aceleravam o afrouxamento da cadeia hierárquica, viram-se divididas em torno de lideranças de origem corporativa. Houve, no período, conflitos entre segmentos hierárquicos de uma mesma força, entre setores do Exército e da Marinha, entre militares republicanos e monarquistas, entre seguidores de líderes diferentes etc. Ainda que divididas, contudo, as Forças Armadas se tornaram um ator político protagonista, tanto por seu papel institucional de avalista de uma transição isenta de ameaças revolucionárias quanto pelo envolvimento direto de muitos de seus membros no processo político.

A condição de elemento de governo agravou, dentro da organização militar, problemas cuja caracterização oscilava entre o disciplinar e o político. Em relação a isso, o marco fundamental não é o 15 de Novembro, mas o conjunto de episódios que, na década de 1880, opuseram segmentos das Forças Armadas ao Estado imperial e ficaram conhecidos como "Questão Militar".

Números de 1886 davam conta de um Exército constituído de 13.500 homens, ao mesmo tempo que registravam 7.526 prisóes por indisciplina ${ }^{6}$. Para julgar os militares, vigiam códigos portugueses

${ }^{1}$ BENJAMIN, Walter. Teses sobre filosofia da história (Tese VIII). In: KOTHE, Flávio (Org.). Walter Benjamin. São Paulo: Ática, 1985. p. 157.

${ }^{2}$ Ver MATTOS, Ilmar Rohloff de. O tempo saquarema. São Paulo: Hucitec, 1987.

${ }^{3}$ COSTA, Emília Viotti da. A Proclamação da República. In: . Da Monarquia à República. Momentos decisivos. 2. ed. São Paulo: Ciências Humanas, 1979. p. 291-326.

${ }^{4}$ A propósito, ver LEMOS, Renato. A alternativa republicana e o fim da monarquia. In: GRINBERG, Keila; SALLES, Ricardo (Org.). O Brasil Imperial. Rio de Janeiro: Civilização Brasileira, 2009. v. III 1870-1889, p. 401-444.

${ }^{5}$ Os parágrafos que se seguem estão baseados em LEMOS, Renato. Justiça Militar e ordem republicana no Brasil: da linha de comando à defesa do Estado (1889-1895). In: ENCONTRO REGIONAL DA ASSOCIAÇÃO NACIONAL DE HISTÓRIA (ANPUH), XII, 2006, Niterói. Anais eletrônicos. Disponível em: <www.rj.anpuh.org/conteudo/view?ID_ CONTEUDO=303\#indice>. Acesso em: 24 nov. 2011.

${ }^{6}$ COSTA, Emília Viotti da. A Proclamação da República. In: . Da Monarquia à República, op. cit. p. 322. 
seculares. Ainda sob a monarquia, houve quem considerasse esses diplomas legais inadequados e os discutisse na Assembleia Geral - mas, "quando o Império caiu, ainda não possuíam as Forças Armadas as leis penais atualizadas" 7 . Um oficial que participou diretamente do golpe republicano identificou no funcionamento da justiça castrense um dos mais fortes fatores de desgaste nas relaçóes entre os militares e o Estado imperial:

(...) a Justiça Militar, cujos processos devem ser simples, claros e retos, era entregue aos sofismas e ajeitamentos de uma hermenêutica sutil e às exigências de um nepotismo impudente, originando-se aí o abatimento do espírito militar que assistia sobressaltado a controvérsias incabidas e a aplicaçôes especiosas das leis ${ }^{8}$.

De fato, as normas e práticas da Justiça Militar brasileira espelhavam a linha de comando em que se inseriam, isto é, as singularidades da organização militar nacional. Já está consolidada na historiografia a importância dos processos militares na conformação das formaçóes estatais, em geral, e das modernas, em particular'. A Inglaterra, no século XVII, e a Rússia, os Estados Unidos da América e a França, no século XVIII, são exemplos de sociedades cujos processos formadores ensejaram que os regulamentos militares antecedessem as primeiras constituições políticas ou as integrassem ${ }^{10}$. A exacerbada feição militar decorrente das guerras de Reconquista, ao mesmo tempo que explica a precocidade de Portugal em relação a esses países, aponta um importante tipo de influência sobre o processo de formação do Estado nacional brasileiro.

Tributário da legislação lusitana, um dos primeiros diplomas legais baixados por d. João VI, mal chegado ao Brasil, foi o alvará que criou o Conselho Supremo Militar e de Justiça (CSMJ) em 1ํㅡㄹ de abril de 1808. Sediado na cidade do Rio de Janeiro, o órgão dividia-se em Conselho Supremo Militar, com funçôes administrativas (requerimentos, cartas patentes, promoçóes, soldos, reformas, nomeaçóes, lavratura de patentes e uso de insígnias, sobre as quais emitia parecer), e Conselho de Justiça, com funçóes judiciárias, julgando, em última instância, os processos criminais dos "réus sujeitos ao foro militar", originários dos conselhos de guerra, que funcionavam como uma primeira instância judiciária. O CSMJ seguia as Ordenaçôes Filipinas, os Artigos de Guerra do "Regulamento do Conde de Lippe" e a Provisão 359, pela qual, enquanto inexistisse lei específica para os crimes militares, seriam considerados como tais aqueles assim tipificados pelas leis militares e somente quando cometidos por militares ${ }^{11}$. A partir de 1830, o CSMJ se orientaria também pelo Código Criminal e pelo Código de Processo Criminal do Império (1832).

Por meio do CSMJ, órgão a um só tempo administrativo e judicial, criavam-se condiçóes para que a justiça castrense cumprisse um papel central na consolidação da função geral do aparelho militar durante a fase monárquica independente: manutenção da ordem político-social e da unidade territorial. O julgamento das práticas individuais dos militares, no exercício da função institucional das Forças Armadas ou não, ficava adstrito a instâncias corporativas. Embora não explicitado no Alvará de 1808 nem na Constituição de 1824, contavam os militares com foro especial, tanto em termos disciplinares quanto criminais. Por isso, a partir daí a definição de "crime militar" mobilizaria tanta energia de juristas e políticos ao longo da história.

\footnotetext{
${ }^{7}$ ARARIPE. Tristão de Alencar. Aspectos particulares da conjuntura. A Justiça Militar e os interesses da segurança nacional. Rio de Janeiro: Escola Superior de Guerra. Departamento de Estudos, C - 79 - 61, 1961. p. 13-14.

${ }^{8}$ Carta do tenente-coronel Jacques Ourique ao Jornal do Commercio, do Rio de Janeiro, em 10 de dezembro de 1889 , transcrita em PORTO, Manuel Ernesto de Campos. Apontamentos para a história da República dos Estados Unidos do Brasil. Rio de Janeiro: Imprensa Nacional, 1890. p. 959.

${ }^{9}$ Ver, por exemplo: ENGELS, Friedrich. Anti-Dühring. 1878. Seção II; WEBER, Max. Economia e sociedade. Brasília: Editora da Universidade de Brasília, 1999. v. 2, Capítulo IX; TILY, Charles. Coerção, capital e estados europeus, $1990-1992$. São Paulo: Editora da Universidade de São Paulo, 1996.

${ }^{10}$ FERREIRA, Pinto. Curso de direito constitucional. Rio de Janeiro: Freitas Bastos, 1964. p. 331.

${ }^{11}$ BASTOS, Paulo César. Superior Tribunal Militar. 173 anos de história. Brasília: Superior Tribunal Militar, 1981. p. 21.
} 
Diferentemente da noção de transgressão disciplinar — infração relacionada com o serviço, punida facultativamente em instância administrativa — o crime — de modo geral, qualquer conduta que transgrida as prescriçóes do Código Penal, punida necessariamente pelo Estado através da justiça penal — pode ser punido com reclusão ou detenção e/ou multa. O crime militar, em sua definição mais genérica, é a conduta tipificada no Código Penal Militar. A crimes que só podem ser cometidos por militares, como a deserçáo e a insubordinação, costuma-se chamar de "propriamente" militares. "Impropriamente" ou "acidentalmente" militares são aqueles que, comuns em sua natureza, podem ser praticados por qualquer pessoa, civil ou militar, mas que, quando cometidos por militar em certas circunstâncias, são considerados militares, por causarem prejuízos à administração, à hierarquia ou à disciplina - por exemplo: homicídio, lesão corporal, furto, roubo, apropriação indébita, estelionato e receptação ${ }^{12}$. A definição do "crime impropriamente militar" é o caminho por onde passa a instrumentalização política da Justiça Militar. Trata-se de uma operação conceitual pautada por variáveis cuja percepção é extremamente plástica: "anormalidade da época ou do tempo em que são cometidos"13 é uma das mais ilustrativas circunstâncias apontadas para caracterizar essa categoria de crime.

A Justiça Militar brasileira tem passado por alguns processos de transição político-institucional, adequando-se a regimes políticos e formaçôes estatais de tipos variados. Alteraçôes em sua base de referência doutrinária e sua estrutura organizacional têm se combinado com continuidades, num amálgama típico das formas como se têm dado as mudanças políticas em nossa sociedade.

O Brasil monárquico não conheceu, a rigor, um direito penal militar, embora se tenham registrado várias tentativas parlamentares de sistematizar as normas e regulamentos em um código. Segundo um estudioso do problema:

A pluralidade de tribunais e a multiplicidade de suas funçôes; a estreita subordinação da justiça ao comando militar; a inexistência de uma codificação de leis substantivas e adjetivas; a falta de um discrime nítido entre os delitos militares e comuns; e a defeituosa classificação das infraçóes à lei penal e à disciplina militar estavam a clamar por uma reforma orgânica e urgente.

Arrastavam-se os processos em juízo e quase sempre terminavam por um ato de arbítrio e não por um ditame da justiça.

A necessidade dessa reforma era não só uma aspiração comum nos círculos militares, como um fato trabalhado no parlamento e fora dele.

Diversos escritores se ocuparam do assunto e numerosos parlamentares apresentaram projetos a respeito ${ }^{14}$.

Durante o período, porém, não se operaram alteraçôes importantes na base legal, na função e na estrutura do CSMJ. Diria mais tarde, já na República, um defensor da reforma da legislação da Justiça Militar: "Os Anais do Parlamento brasileiro, a partir de 1826, assinalam os patrióticos esforços que, infelizmente, só lograram enriquecer o nosso patrimônio jurídico com uma legislação de retalhos, sem sistematização e homogeneidade" 15 .

Talvez refletindo o espírito civilista prevalecente durante o Império, a jurisdição militar ficou sob regulação das leis ordinárias ${ }^{16}$. Diversas iniciativas no sentido de fazer mudanças em sua estrutura es-

\footnotetext{
${ }^{12}$ NEQUETE, Lenine. O Poder Judiciário no Brasil a partir da Independência. II — República. Brasília: Supremo Tribunal Federal, 2000. p. 34.

${ }^{13}$ BANDEIRA, Esmeraldino O. T. Curso de direito penal militar. Rio de Janeiro: Francisco Alves, 1915. p. 13.

${ }^{14}$ BANDEIRA, Esmeraldino O. T. Direito, justiça e processo militar. Rio de Janeiro: Francisco Alves, 1919. p. 187.

${ }^{15}$ Exposição do deputado Cândido Mota na Câmara dos Deputados em 25 de agosto de 1911 apud BANDEIRA, Esmeraldino O. T. Direito, justiça e processo militar, op. cit. p. 188.

16 "A constituição do Império não continha disposiçôes expressas no tocante à jurisdição militar, cuja existência apenas a lei ordinária assegurava.” BASTOS, Paulo César. Superior Tribunal Militar, op. cit. p. 29.
} 
tacionaram nas comissóes do Parlamento ${ }^{17}$. Na condição de ministro da Guerra, Luís Alves de Lima e Silva, então conde de Caxias, por exemplo, adotou e sugeriu medidas nesse sentido. A Comissáo de Exame da Legislação do Exército na Câmara dos Deputados analisou suas propostas, que chegaram a ser incorporadas aos anteprojetos de Código Penal e de Código do Processo encaminhados à Assembleia Geral em 1867. E lá permaneceriam por mais de vinte anos, só vindo a questáo das leis penais militares a ser atacada, em termos práticos, na República ${ }^{18}$.

Não é de estranhar, portanto, que os primeiros momentos da presença das Forças Armadas no governo republicano ficassem caracterizados pelo impacto da função política sobre as normas disciplinares. Derrubada a monarquia no Brasil em 15 de novembro de 1889, os novos ministros militares, desde logo, chamaram a atenção do Governo Provisório republicano (1889-1891) para o anacronismo da legislação judiciária militar ${ }^{19}$, principalmente no tocante à disciplina. Antes mesmo de se iniciar a reforma da legislação penal militar, foi baixado, no dia 16, decreto que aboliu os castigos corporais na Marinha e reduziu o tempo de serviço militar obrigatório. As duas medidas buscavam eliminar tradicionais focos de insatisfação entre os marinheiros. Podem ser entendidas, também, como uma tentativa de evitar que eles fossem manobrados por oficiais monarquistas e jogados contra a nova ordem política.

O Governo Provisório tomou algumas iniciativas no sentido da elaboração de novos regulamentos disciplinares e criminais para a área militar, mas as disputas decorrentes do processo de reorganização política do Estado dificultaram a tarefa ${ }^{20}$. A posição pública do governo apontava o problema como prioritário, porque entendido como um direito das "classes militares", sofredoras disciplinadas durante a monarquia e fautoras gloriosas da "revoluçáo de 15 de novembro" 21 . Em 14 de janeiro de 1890, o ministro da Guerra, tenente-coronel Benjamin Constant Botelho de Magalhães, nomeou uma comissão para elaborar o Código Penal e de Processo Militar. Resultou daí o projeto do Código de Justiça Militar para o Exército Brasileiro, dividido em três partes: Código Criminal, Código de Processo Criminal e Código Disciplinar. Contudo, a substituição de Benjamin Constant pelo general Floriano Peixoto à frente do Ministério da Guerra, poucos meses depois, resultou na interrupção dos trabalhos da comissão do Exército $^{22}$. Continuaram em vigor, portanto, no Exército, os códigos e regulamentos herdados do Império.

Quanto à Marinha, a pressão de oficiais levou o governo a rever a abolição dos castigos físicos e a criar a Companhia Correcional (12 de abril de 1890). Considerava-se que "o castigo severo" era "uma necessidade reconhecida e reclamada por todos os que exercitam a autoridade sobre o marinheiro". A nova unidade da Marinha se destinava a isolar e punir sumariamente marinheiros de "má conduta habitual" em casos que não exigissem a formação de conselho de guerra, primeira instância da Justiça Militar. As sançôes previstas iam de "prisão e ferro na solitária, a pão e água", a "chibatadas". O objetivo era "corrigir" o praça no prazo de três meses, após o que ele retornaria à sua unidade de origem. Se resistisse a corrigir-se, sofreria "maior castigo que os combinados no presente regulamento", a ser determinado de acordo com o "prudente arbítrio do comandante", independentemente, portanto, das instâncias formais da Justiça Militar. Ainda em 1890, o governo decretou o Código Disciplinar da Armada (21 de junho),

\footnotetext{
${ }^{17}$ SOUZA, Adriana Barreto de. A Justiça Militar no Império. In: CASTRO, Celso; D’ARAÚJO, Maria Celina (Coord.). 200 anos de Justiça Militar. Rio de Janeiro: Cpdoc, 2007. p. 42-47.

${ }^{18}$ ARARIPE, Tristão de Alencar. Aspectos particulares da conjuntura, op. cit. p. 13-14.

${ }^{19}$ Ibidem.

${ }^{20}$ LEMOS, Renato. A Justiça Militar na República. In: CASTRO, Celso et al. (Org.). 200 anos de Justiça Militar. Rio de Janeiro: Cpdoc/FGV, 2007. p. 76.

21 “Mensagem dirigida por Deodoro da Fonseca ao Congresso na primeira sessão dos trabalhos constituintes", transcrita em: BONAVIDES Paulo; ANDRADE, Paes de. História constitucional do Brasil. 4. ed. Brasília: Ordem dos Advogados do Brasil, 2002. p. 645-654.

${ }^{22}$ ARARIPE, Tristão de Alencar. Aspectos particulares da conjuntura, op. cit. p. 13-14.
} 
aboliu a pena de galés e reduziu para trinta anos as penas perpétuas (20 de setembro), e instituiu o Código Penal da Armada (11 de outubro), que, no entanto, seguiria uma trajetória tortuosa, resultado das polêmicas que despertou ${ }^{23}$.

Um dos traços mais nítidos do Governo Provisório foi a ânsia "codificadora”. Entretanto, mais do que elaborar códigos que representassem uma inovação republicana, tratava-se de dar um fecho à obra monárquica, constituindo, portanto, mais um traço de continuidade no processo de transição política.

Quando sobreveio a República, estavam em andamento projeto de Código Civil e a reforma do Código Criminal de 1830. Foi dissolvida a comissão encarregada da feitura do Código Civil. (...) O mesmo, entretanto, não ocorreu em relação ao Código Penal, porquanto foi resolvido incumbir-se da sua elaboração em curto prazo o conselheiro Baptista Pereira (... $)^{24}$.

Como todo movimento contrarrevolucionário, o republicano, uma vez no poder, procurou valer-se dos poderes excepcionais que, na condição de ditadura, o Governo Provisório concentrava, para fazer da manutenção da ordem sua divisa principal. É o que evidenciam os seguintes extratos, em especial os grifados, da primeira proclamação republicana, assinada pelo general Deodoro da Fonseca e dirigida a seus concidadãos:

Como resultado imediato desta revolução nacional, de caráter essencialmente patriótico, acaba de ser instituído um governo provisório, cuja principal missão é garantir com a ordem pública a liberdade e o direito do cidadão. (...) O Governo Provisório, simples agente temporário da soberania nacional, é o governo da paz, da liberdade, da fraternidade e da ordem. No uso das atribuiçóes e faculdades extraordinárias de que se acha investido, para a defesa da integridade da pátria e da ordem pública, o governo provisório, por todos os meios a seu alcance, promete e garante a todos os habitantes do Brasil, nacionais e estrangeiros, a segurança da vida e da propriedade, o respeito aos direitos individuais e políticos, salvas, quanto a estes, as limitaçóes exigidas pelo bem da pátria e pela legítima defesa do governo proclamado pelo povo, pelo Exército e pela Armada Nacional ${ }^{25}$.

Antes mesmo de elaborada a nova constituição, o Governo Provisório baixou, por meio do Decreto no 847 , de 11 de outubro de 1890, o Código Penal, cujas primeiras linhas deixavam claro não se referir a crimes cometidos por presidentes da República ou por militares. Por outro lado,

(...) se estendeu em detalhes, criminalizando uma multiplicidade de comportamentos. Classificava uma série de delitos como atentatórios à ordem social e política: as conspiraçôes contra a República, os crimes de sedição e outros atos nocivos à segurança nacional ${ }^{26}$. Criminalizava os atos de insubordinação, proibia as reuniōes clandestinas e as aglomerações de pessoas em lugares públicos e recintos fechados, quando classificados como suspeitos ou atentatórios à ordem pública e à segurança da República. Interditava a formação de sociedades secretas, podendo prender os cidadáos que delas participassem. Havia também puniçôes aos que resistissem a mandato legal de autoridade competente ou que desacatassem as autoridades constituídas da República ${ }^{27}$.

\footnotetext{
${ }^{23}$ Reformado a partir de autorizaçáo concedida ao Ministério da Marinha por decreto de 14 de fevereiro de 1891, em 7 de março seria decretada sua versão definitiva. A primeira legislatura ordinária republicana, no entanto, o consideraria inconstitucional e, em 1893, o STF o declararia nulo.

${ }^{24}$ MORAES, Evaristo de. Da monarquia para a república, 1870-1889. 2. ed. Brasília: Editora da Universidade de Brasília. p. 144 apud ALVES, Paulo. A verdade da repressão. Práticas penais e outras estratégias na ordem republicana (1890-1921). São Paulo: Arte \& Ciência; Unip, 1997. p. 32.

${ }^{25}$ Apud ALVES, Paulo. A verdade da repressão, op. cit. p. 16. Grifo meu.

${ }^{26}$ No texto do decreto, a expressão usada é "segurança interna" da República.

${ }^{27}$ ALVES, Paulo. A verdade da repressão, op. cit. p. 19.
} 
Paulo Alves observa que o Código Penal de 1890 constituía, no tocante à questáo da ordem, uma evidente continuidade em relação à Monarquia:

Comparando-se o Código Penal ${ }^{28}$ do Império com o da República, verifica-se, imediatamente, que os artigos deste referentes a insurreiçôes, levantes, sedições, conspirações, são cópia servilíssima, transposição com ponto e vírgula do outro, trocando apenas o que era Império pelo que é República. Assim, o Império, nascido de uma insurreição, condenava a insurreição e a República, nascida de outra insurreição, condena ferozmente qualquer insurreiçãa ${ }^{29}$.

O inimigo da ordem, o foco potencial de insurreição, entretanto, não eram - com certeza, não prioritariamente - os defensores da monarquia. O campo monarquista — cujo estado de decaimento vinha se acentuando, pelo menos, desde 1868, o que ajuda a explicar a facilidade com que o golpe republicano foi vitorioso - encontrava-se mortalmente atingido pelo vírus da "aderite". O adesismo desenfreado dos "republicanos de 16 de novembro" desqualificava, na prática, os monarquistas como um inimigo a ser levado a sério pelo governo republicano.

O espectro da reação monarquista deu, contudo, ensejo a uma série de medidas preventivas de exceção por parte do Governo Provisório ${ }^{30}$. Para desestimular aventuras subversivas, em 23 de dezembro de 1889 foi baixada uma medida que ameaçava os indivíduos que conspirassem contra a República e seu governo com julgamento por uma comissão militar e punição por crime de sedição. Para executá-la, foi organizada a Comissão Mista Militar de Sindicâncias e Julgamentos, um tribunal tipicamente de exceção, inclusive porque criado por um governo que se regulava por uma Constituição provisória por ele mesmo baixada ${ }^{31}$. A Comissão não mirava apenas a oposição monarquista, nem pretendia conter somente a indisciplina militar, cuja dimensão política se ampliava. Desaparecido o inimigo comum monárquico, fator de unidade corporativa, conflitos no interior das Forças Armadas poderiam ter efeitos dissolventes sobre a ordem política. $\mathrm{O}$ temor de uma união de militares dissidentes com setores populares, como se esboçara no Motim do Vintém em 1881, certamente também esteve subjacente à política preventiva e repressiva do Governo Provisório ${ }^{32}$. O alvo efetivo eram classes e categorias sociais identificadas como "perigosas" para a ordem:

Entre 1890 e 1927 (...), quase uma dezena de leis e decretos foram instaurados para efetivar o controle sobre os vadios, mendigos, desempregados e capoeiras, sem contar os onze artigos do Código Penal que esquadrinhavam esses delitos e impunham penas amargas àqueles que fossem contemplados nos dispositivos penais da Primeira República.

Da mesma forma, o governo republicano consagrou outros seis decretos e leis estabelecendo o instituto repressivo da expulsão, deportação e desterro daqueles que eram considerados agitadores, desordeiros e inimigos da República. (...) O sistema penal abrangia de maneira efetiva a esfera das manifestaçóes políticas e sociais, reprimindo as condutas consideradas antissociais que, não por acaso, eram o modo de ser de muitos grupos subalternos da sociedade, como os pobres, os desempregados, os vadios e os ativistas que atuavam junto ao movimento operário ${ }^{33}$.

\footnotetext{
${ }^{28}$ Código Criminal do Império, de 1830.

${ }^{29}$ OITICICA, José. Artigo em Spartacus, Rio de Janeiro, ano I, n. 16, 15 de novembro de 1919 apud ALVES, Paulo. A verdade da repressäo, op. cit. p. 15.

${ }^{30}$ LEMOS, Renato. Benjamin Constant. Vida e história. Rio de Janeiro: Topbooks, 1999. p. 461.

${ }^{31}$ Sobre a atividade legislativa do Governo Provisório, ver LEAL, Aurelino. História constitucional do Brasil. Rio de Janeiro: Imprensa Nacional, 1915. p. 201-204.

${ }^{32}$ LEMOS, Renato. Benjamin Constant. Vida e história, op. cit.

${ }^{33}$ ALVES, Paulo. A verdade da repressão, op. cit. p. 28 e 30.
} 
Tratava-se, portanto, antes de tudo, de assegurar a ordem social de que o Estado republicano se constituía como garantidor, assim como o Estado monárquico o fizera. O quadro de disputas políticas que se seguiu à promulgação da carta constitucional republicana (24 de fevereiro de 1891) evidenciou a utilidade da Justiça Militar como instrumento de defesa do Estado, mas também do governo do momento. Assim, durante a presidência do, agora, marechal Floriano Peixoto (1891-94), fortalecer-se-ia progressivamente a ideia de militarizar o enquadramento penal dos crimes políticos, perspectiva que se tornaria oficial sob regime democrático, em 1935, e durante a ditadura instituída no Brasil a partir de 1964. Trata-se de uma operação jurídico-política de conversão de atos políticos em crimes militares ou de deslocamento daqueles para a jurisdição castrense ${ }^{34}$.

\section{A criação do Supremo Tribunal Militar (STM)}

Em dezembro de 1889, o Governo Provisório deu início aos preparativos para a Assembleia Nacional Constituinte. Por decreto do dia 3, nomeou uma comissão especial — Comissão de Juristas para elaborar o projeto de Constituiçáo que serviria de ponto de partida para os trabalhos dos futuros congressistas.

A Justiça Militar não foi objeto do projeto final da comissão. Parece ter prevalecido uma concepção de crime militar que privilegiava a condição do agente, e não o bem tutelado. Isso explicaria por que a definição do foro para julgamento dos crimes militares foi definida na "Declaração de direitos" do projeto constitucional. Dizia o artigo 100 desse título: "O foro é comum, respeitadas as restriçóes desta Constituição e as originadas da lei militar". Quanto a esta, dizia o artigo 113 do título "Disposiçôes gerais": "O Congresso, por lei especial, fará revisão, quanto antes, das atuais leis militares e de seu respectivo processo". A formulação genérica expressava, segundo Wilma Peres Costa, "o pensamento bacharelesco em relação ao papel das Forças Armadas, dada a liberdade dos trabalhos da comissão e a ausência de representação militar em seu interior" ${ }^{35}$.

Os dois artigos mencionados foram, porém, suprimidos pelo então ministro da Fazenda, Rui Barbosa, que, por decisão do Governo Provisório, reviu e modificou muitas partes do projeto que foi apresentado à Assembleia Nacional Constituinte, instalada em 15 de novembro de 1890. O projeto do Governo Provisório foi, portanto, ainda mais omisso do que o da Comissão de Juristas em relação à Justiça Militar, que permanecia um assunto restrito à linha de comando. Ainda assim, a Mensagem dirigida por Deodoro da Fonseca ao Congresso na primeira sessão dos trabalhos constituintes ${ }^{36}$ apontava o tema como um dos pontos em que a República deveria se distinguir da ordem monárquica. Tratava-se, antes de tudo, de fazer as "reparaçóes a que as classes militares tinham incontestável direito", porque a Armada e o Exército teriam sido as duas "classes" que mais haviam "sofrido sem se rebelar" durante o Império, e a elas cabia "a glória de ter efetuado a revolução de 15 de novembro". O momento político era de reforma de todo o "organismo judiciário", já tendo sido instituído o Código Penal e encomen-

\footnotetext{
${ }^{34}$ A respeito, ver LEMOS, Renato. Justiça Militar e ordem republicana no Brasil: da linha de comando à defesa do Estado (1889-1895), op. cit.

${ }^{35}$ COSTA, Wilma Peres. Os militares e a primeira constituição republicana. In: MORAES, João Quartim de et al. A tutela militar. São Paulo: Vértice, 1987. p. 33. O texto transcreve e analisa artigos do projeto da Comissão de Juristas diretamente relacionados a assuntos militares. Ernesto Senna transcreve outros artigos do projeto: SENNA, Ernesto. Deodoro: subsídios para a história. 2. ed. Brasília: Editora da Universidade de Brasília, 1981. O texto produzido pela Comissão de Juristas e as emendas de Rui Barbosa estão em BARBOSA, Rui. Obras completas. Rio de Janeiro: Ministério da Educação e Saúde, 1946. V. XVII (1890), Tomo I, A Constituição de 1891. É transcrito, ainda, em LYRA, Augusto Tavares de. Organização política e administrativa do Brasil. São Paulo: Companhia Editora Nacional, 1941.

36 Transcrita em BONAVIDES, Paulo; ANDRADE, Paes de. História constitucional do Brasil, op. cit. p. 645-654.
} 
dado um projeto de Código Civil. Cabia, então, reformular também as normas que regulavam a vida das "classes militares", porque a "preocupação do antigo regime foi sempre a de trazê-las jungidas à ignorância, reduzi-las a instrumentos passivos, oprimi-las pelo sistema bárbaro do terror, submetendo o soldado, revel ao dever, a um sistema penal tirânico”. Era, pois, tarefa prioritária do governo republicano "providenciar para que o Código Militar fosse organizado, tendo em vista, principalmente, a justiça, que não pode ser para o soldado a tortura ou a degradação social" ${ }^{37}$.

A comissão formada dentro da Constituinte para examinar e dar parecer sobre o projeto do Governo Provisório - Comissão dos 21 - composta por representantes de todos os estados e do Distrito Federal, parece ter seguido a orientação do marechal. Tanto é que aprovou duas emendas relativas ao julgamento de crimes militares. A primeira dizia: "Os militares de terra e mar terão foro especial, constituído por membros da sua classe, nos crimes militares”. Pela outra, a revisão das sentenças atribuídas em primeira instância nos casos de crimes militares seria feita em um tribunal a ser criado de acordo com emenda substitutiva à da Comissão dos 21 no tocante às "Disposiçôes gerais", que estatuía:

Haverá um Supremo Tribunal Militar com as seguintes atribuiçóes:

1o Julgar em última instância os crimes de natureza militar, não lhe sendo lícito, em caso algum, agravar a pena.

2ำ Emitir parecer sobre assuntos que forem submetidos ao seu exame, não podendo as suas decisóes ter execução sem o "Cumpra-se" do presidente da República.

$\$ 1^{\circ}$ Este tribunal compor-se-á de doze membros ${ }^{38}$ com o título de vogais, compreendidos neste número quatro jurisconsultos de notável saber, todos nomeados pelo presidente da República e sujeita a nomeação à aprovação do Senado.

$\$ 2^{\circ}$ Os vogais militares serão oficiais-generais do Exército e da Armada, efetivos ou reformados, em igualdade de proporção entre as duas classes, e tanto estes quanto os civis só perderão o lugar por efeito de sentença.

$\$ 3$ o Fica extinta a categoria de conselheiros de Guerra, salvos os direitos adquiridos.

$\$ 4^{\circ}$ Em regulamento especial, sujeito à aprovação do Congresso, o governo estabelecerá o modo como deverá este Tribunal funcionar, conferindo-lhe, dentro dos limites da lei, outras atribuiçóes claramente definidas.

Ficava, portanto, incluída na jurisdição do futuro STM a revisão de penas em processos criminais militares. No plenário, houve debate em torno dessa questão, sendo aprovada emenda ${ }^{39}$ que estabelecia o foro especial militar em duas instâncias, mas não especificava as competências da segunda:

\footnotetext{
${ }_{37}$ Observe-se que, apesar de criticar a legislação penal militar, Deodoro, respondendo a uma saudação feita por um congressista e buscando afirmar as vantagens de sua formação militar para o exercício dos cargos de chefe do Governo Provisório e provável futuro presidente constitucional, buscou amparo nos códigos que acabara de negar: "Educado na aritmética positiva do Conde de Lippe, quer como soldado quer como homem do governo, jamais desconheci a necessidade de respeitar a lei, o direito e a justiça, e, qualquer que seja de ora em diante a minha posição, hei de manter e cumprir a Constituiçáo dos Estados Unidos do Brasil”. Ibidem.

${ }^{38}$ Debateu-se a composição do novo tribunal. Emenda subscrita por destacados oficiais parlamentares, como José Simeão, José de Almeida Barreto e Custódio de Melo, propôs que o integrassem doze membros militares, como acontecia no Conselho Supremo Militar e de Justiça, e "quatro desembargadores de notável saber, todos nomeados pelo presidente da República, sujeita a nomeação à aprovaçáo do Senado”. Já a subemenda à emenda aditiva da comissão, apresentada pelo militar e deputado - que, por dois meses, presidira o estado do Piauí em 1890 e seria presidente, depois, do estado de Alagoas (1892-94) — Gabino Besouro, propunha que os membros militares fossem quinze, e os "jurisconsultos", três.

${ }^{39} \mathrm{O}$ autor da emenda foi Manoel Prisciliano de Oliveira Valadão, tenente-coronel e deputado por Sergipe, secundado por Gabino Besouro. Os Anais da Assembleia Nacional Constituinte registram, também, emenda ao mesmo artigo, de autoria do deputado Retumba, não aprovada, em que se substituía a expressão "crimes militares" por "delitos militares".
} 
Art. 77 - Os militares de terra e mar terão foro especial nos delitos militares.

$\$ 1^{\circ}$ Esse foro compor-se-á de um Supremo Tribunal Militar, cujos membros serão vitalícios, e dos conselhos necessários para a formação da culpa e julgamento dos crimes.

$\$ 2^{\circ}$ A organização e atribuiçóes do Supremo Tribunal Militar serão reguladas por lei.

O primeiro-tenente, e deputado pela Paraíba, João da Silva Retumba procurou salvar o sentido da redação anterior. Entendia que nela o STM era tratado como matéria constitucional, ao contrário do que se passava no "regime decaído", que apenas tolerara o Conselho Supremo Militar e de Justiça. O STM deveria equiparar-se ao Supremo Tribunal Federal (STF): "que julgue na parte militar, como este na parte civil". Por isso, lhe parecia que, "criados, na Constituição, tribunais superiores, um civil e outro militar, ambos devem, somente, ocupar-se de assuntos que lhe disserem respeito". A regra se aplicaria também à função revisional. Se era facultado ao STF proceder à revisão de processos findos, a mesma competência deveria ser atribuída ao STM, em se tratando de processos militares: "não só a boa lógica isso aconselha, como, principalmente, haverá uniformidade na lei”. Ficariam, assim, "ambos os tribunais, civil e militar, com poderes, conferidos pela Constituição, para rever processos, podendo em qualquer tempo, e somente em benefício dos condenados, reformar, ou confirmar, as sentenças neles lavradas". Prevaleceu, entretanto, o estabelecido no projeto do Governo Provisório, pelo qual os processos findos, em matéria criminal, inclusive os militares, "poderiam" ser revistos no STF ${ }^{40}$.

Embora mantida fora do Poder Judiciário, a Justiça Militar foi a única justiça especializada prevista na primeira Constituição republicana ${ }^{41}$. Como foi entendida do ângulo de quem cometia o crime, integrou a "Declaração de direitos". Entretanto, alguns constituintes a trataram como uma questão de Estado, aproximando-a da função atribuída ao Judiciário civil, encabeçado pelo STF. Essa perspectiva se fortaleceria graças à determinaçáo constitucional de que a regulamentação das atividades do Supremo Tribunal Militar se fizesse por iniciativa do Executivo, embora dependendo da aprovação do Congresso.

\section{A Justiça Militar e a luta política sob Floriano Peixoto}

O papel da Justiça Militar durante o mandato presidencial de Floriano Peixoto (23/11/1891 — 15/11/1894) resultou da disputa pela direção estatal entre fraçóes do bloco que se tornou dominante com a ruptura política de novembro de 1889. As linhas de força do regime político democrático e da organizaçáo estatal republicano-democrática se haviam definido no período 1888-1891. Com a abolição da escravidão, operou-se uma transformação nas relaçóes de produção e no direito que potencializou a modernização capitalista ${ }^{42}$ e não era incompatível com a organizaçáo monárquica. A primeira Constituição republicana, mais do que formalizar o fim da monarquia, estabeleceu um novo pacto de poder, naturalmente, entre as fraçôes das classes dominantes e as correntes políticas aliadas. O governo de Floriano, assim como a fase constitucional do presidente Deodoro da Fonseca (fevereiro a novembro de 1891) constituíram um momento de ajuste das condiçóes políticas estaduais a esse pacto, bem como de definição das bases hierárquicas em que a federação seria praticada no Brasil até 1930.

A articulação entre esses dois pontos de ruptura - no plano das relaçóes de produção e do direito e do formato do Estado - constitui o terreno em que proliferaram e se enfrentaram iniciativas políticas

\footnotetext{
${ }^{40}$ A emenda sobre a revisão dos processos militares foi aceita integralmente na primeira discussão, mas, "na redação para a segunda discussáo, foi suprimida, sem qualquer explicação, a última parte, ficando a competência com o Supremo Tribunal Federal e não com o Supremo Tribunal Militar (...)". ROURE, Agenor de. A Constituinte republicana. 2. ed. Brasília: Senado Federal; Editora da Universidade de Brasília, 1979. v. 2.

${ }^{41}$ NEQUETE, Lenine Nequete. O Poder Judiciário no Brasil a partir da Independência, op. cit. p. 34.

${ }^{42}$ A propósito, ver SAES, Décio. A formação do Estado burguês no Brasil (1888-1891). Rio de Janeiro: Paz e Terra, 1985.
} 
mais diretamente ligadas às condiçóes objetivas de existência das classes e categorias sociais do que as disposiçóes constitucionais, restritas ao campo formal. Deste ponto de vista, a Justiça Militar cumpriu um papel determinado por sua condição de instituição estatal, da mesma maneira, em termos gerais, que qualquer instituição de igual natureza. Mas, cumpriu esse papel de maneira específica na medida da sua função disciplinar e repressora, especialmente propícia a uma instrumentalização por parte do Executivo, já que a Constituição de 1891 a definiu tal como a monarquia, isto é, como parte da organização militar ${ }^{43}$.

Estando a sociedade brasileira, desde fevereiro de 1891, já regida pela primeira Constituição republicana, os problemas ligados às relaçóes militares deflagraram tensóes no relacionamento entre os poderes Executivo, Judiciário e Legislativo. Após a tentativa de golpe e consequente renúncia do presidente Deodoro da Fonseca em novembro de 1891, partidários seus promoveram rebeliōes militares no mês seguinte, articulando-se a movimentos de protestos civis nas ruas e no Congresso contra a efetivação do vice, marechal Floriano Peixoto, na presidência da República. Em janeiro de 1892, Manuel de Campos Sales, no Senado, e Inácio Serzedelo Correia, na Câmara, conseguiram o fim das sessões do Congresso para que o governo "pudesse agir sozinho, sem embaraços parlamentares e na plenitude de suas prerrogativas, tanto em bem da manutenção da ordem, como na repressão aos elementos perturbadores" ${ }^{4}$. Estava apresentada a senha para o estabelecimento de situaçóes de exceção que permitiriam ao Executivo instrumentalizar politicamente todos os recursos jurídicos do Estado.

Em abril, treze generais que, por meio de um manifesto, pressionaram politicamente Floriano Peixoto foram demitidos de suas comissôes e reformados administrativamente. Em seguida, foi decretado o estado de sítio para o Distrito Federal, ficando suspensas as garantias constitucionais por 72 horas. Dois dias depois, decreto presidencial determinou a prisão de militares e civis, muitos dos quais foram desterrados para áreas distantes no Norte do país. Pedido de habeas corpus em favor dos presos foi negado pelo STF por um voto, resultado atribuído a ameaças que Floriano teria feito aos juízes. Quando, em 1893, o STF declarou a nulidade do Código Penal da Armada, surgiram no Congresso acusaçóes de crime de abuso de autoridade. E Floriano Peixoto, em represália, passou a obstar o funcionamento do tribunal, deixando, por meses, de preencher as vagas que se abriam e recusando-se a empossar o presidente eleito pela casa, função que lhe cabia por determinação constitucional ${ }^{45}$.

As tensóes entre representantes dos poderes se aguçaram com a Revolução Federalista ${ }^{46}$, deflagrada em fevereiro de 1893. No que diz respeito à Justiça Militar, colocou-se em questáo o foro militar pela primeira vez na República, em duas situações distintas, mas ambas de natureza política. A primeira, em 25 de julho, referiu-se ao enquadramento do almirante Eduardo Wandenkolk ${ }^{47}$, ex-ministro da Marinha, então senador e um dos líderes da revolta. O que prevaleceria na definição da instância adequada para julgá-lo: a condição de parlamentar, com direito a foro civil, ou a de militar, que o enquadrava no Código Penal da Armada? A segunda situação foi a tentativa de também enquadrar, na legislação penal militar, civis presos durante o movimento e reclusos em unidades militares. Ainda no rastro da revolta de 1893, outras questóes relativas à aplicação do Código foram levantadas. Uma delas lembrava que sua origem era uma autorização concedida pelo Governo Provisório, ditatorial, utilizada indevidamente já no período constitucional ${ }^{48}$ — como já foi mencionado, o Senado acabaria por decidir pela sua incons-

\footnotetext{
${ }^{43}$ Apenas com a Constituição de 1934 ela se deslocaria para o âmbito do Judiciário.

${ }^{4}$ SAES, Décio. A formação do Estado burguês no Brasil (1888-1891), op. cit. p. 70.

${ }^{45}$ RODRIGUES, Leda Boechat. História do Supremo Tribunal Federal. 2. ed. Rio de Janeiro: Civilização Brasileira, 1991.

v. 1 , p. 3 .

${ }^{46}$ Guerra civil que conflagraria o Rio Grande do Sul, Santa Catarina e Paraná até agosto de 1895, em oposição ao governador gaúcho Júlio de Castilhos e ao presidente Floriano Peixoto, que o apoiava.

${ }^{47}$ Ver RODRIGUES, Leda Boechat. História do Supremo Tribunal Federal, op. cit.

${ }^{48}$ Acórdão para o pedido de habeas corpus no 410, de 16 de agosto de 1893, em favor de Mário Aurélio da Silveira, transcrito
} 
titucionalidade e o STF, pela sua nulidade, ainda em 1893. Outra remetia ao artigo 60 da Constituição, que determinava o julgamento de crimes políticos por juízes e tribunais federais civis e, como a Revolta se enquadrava nesse caso, não haveria por que julgar os envolvidos no foro militar ${ }^{49}$.

Ao afirmar, nessas e outras situaçôes que se seguiriam, a adequação do foro civil para crimes políticos, em consonância com a tradição liberal que animava seus membros, o STF entrou em rota de colisão com o Executivo. A regulamentação do estado de sítio foi uma alternativa apresentada no Congresso, mas, segundo o senador que a formulou, bloqueada por partidários do governo que entendiam ser a medida insuficiente e necessário o estabelecimento de tribunais de exceção ${ }^{50}$. Talvez indo nesta direção, o governo de Floriano Peixoto tentou subordinar a estrutura da Justiça Militar por meio de decretos de exceção para se fortalecer em face dos movimentos ameaçadores da ordem.

Em 18 de julho de 1893, finalmente, foi criado o STM, com as mesmas competências consultiva e judiciária do Conselho Supremo Militar e de Justiça, distinguindo-se dele, porém, no tocante à presidência, que deixava de ser ocupada pelo chefe do Executivo, passando a ser funçáo eletiva entre os membros da corte. O STM nasceu, portanto, no olho do furacão dos primeiros anos republicanos.

Diante da Revolta da Armada (6/9/1893) ${ }^{51}$, o governo convocou os oficiais da Marinha e considerou desertores cerca de 305 deles $^{52}$. No dia 10 de setembro, foi decretado o estado de sítio para a Capital Federal e Niterói (RJ). Em seguida, o governo baixou dois decretos, tipicamente de exceção, que indicam a militarização da luta política pela via da identificação entre defesa da ordem interna e defesa do Estado. O Decreto $\mathrm{n}^{\mathrm{o}} 1.681$ (28/2/1894) declarou sujeitos à jurisdição militar os crimes que se relacionassem à rebeliáo em curso, disposição ampliada em 5 de março pelo Decreto no 1685 . Tais medidas republicanas reproduziam o espírito de similares monarquistas adotadas em situação análoga - o Decreto no 61 e o Regulamento no 23, ambos de 24 de outubro de 1838, que estabeleceram, respectivamente, a identificação do "estado de rebeliâo" ao "estado de guerra" para efeitos penais e o entendimento de que as leis específicas para tempo de guerra eram aplicáveis nos lugares que se achassem em "estado de rebelião". Constituía-se, assim, a Justiça Militar, elemento da organização corporativa, em instrumento de defesa do Estado, que o chefe do Executivo e suas bases de apoio militares e civis, no Congresso e fora dele, entendiam estar sendo ameaçado.

A luta política durante o governo de Floriano Peixoto fez com que a consolidação da noção de crime militar se tornasse uma das questóes centrais da elaboração jurídica e parlamentar da época. Até então, prevalecera a ideia de que a jurisdição militar só se aplicaria a civis em tempo de guerra e em crimes de espionagem, tentativa de sedução de praças para que desertassem ou se rebelassem contra seus superiores hierárquicos ou o governo, ataque a sentinelas e entrada em fortificaçôes por meios ilícitos ${ }^{53}$. Em um primeiro momento, os legisladores republicanos redefiniram essas infraçóes como comuns, incluindo-as no Código Penal. O Decreto n⿳ำ 848 , promulgado no mesmo dia que o do Código Penal, reforçou a nova classificação. O Código Penal da Armada, nas duas versóes — de 1890 e 1891 —, estendeu o foro militar a civis em tempo de paz. Esmeraldino Bandeira observa que este código, "para sujeitar a seus dispositivos e, portanto, ao foro militar, os simples paisanos, prescindiu de uma condição primacial —

em RODRIGUES, Leda Boechat. História do Supremo Tribunal Federal, op. cit. p. 161-164.

${ }^{49}$ Acórdão para o pedido de habeas corpus $\mathrm{n}^{-}$771, de 8 de maio de 1895, em favor do tenente-coronel José Facundo da Silva Tavares transcrito em RODRIGUES, Leda Boechat. História do Supremo Tribunal Federal, op. cit. p. 161-164.

50 SALES, Campos. Da propaganda à presidência. Brasília: Editora Universidade de Brasília, 1983. p. 63.

${ }^{51}$ Levante da esquadra sediada na baía da Guanabara, no Rio de Janeiro, em oposição a Floriano Peixoto, que se estenderia a março de 1894 sob a chefia, inicialmente, do almirante Custódio de Melo e, depois, do almirante Luís Felipe Saldanha da Gama.

${ }^{52}$ CARONE, Edgard. A República Velha (evolução política). São Paulo: Difusão Europeia do Livro, 1971. p. 109. O autor menciona a recusa de oficiais da ativa a comandar a esquadra governista contra os revoltosos. Ibidem, p. 111.

${ }^{53}$ BANDEIRA, Esmeraldino O. T. Curso de direito penal militar, op. cit. p. 40. 
o estado de guerra" 54 . Entretanto, contrariando o governo, a sentença no 410 do STF (16/8/1894) determinou que civis acusados de crimes de sedução de praças para a deserção ou para se levantarem contra o governo só poderiam ser processados no foro militar quando em estado de guerra externa. Em seguida, já no final do mandato de Floriano Peixoto, a Lei no $221(20 / 11 / 1894)^{55}$ classificou como políticos esses crimes e determinou seu julgamento em tribunal federal civil.

Em um período ainda de regulamentação das determinações gerais da Constituição recém-promulgada, a definiçáo do grau de autonomia da Justiça Militar também constituía uma questão de natureza política. A Lei no 221 estabeleceu que o STF teria poder de revisão das sentenças criminais proferidas pelo STM. Esse recurso não fora previsto pela Constituição nem pelo Código Penal da Armada e significava importante mecanismo de controle civil sobre a Justiça Militar. As medidas de predomínio civil sobre a justiça castrense seriam, contudo, contrabalançadas, já no governo de Prudente de Morais (1894-98) — ironicamente, um civil —, pelo Regulamento Processual e Criminal Militar (RPCM), expedido pelo STM em 16 de julho de 1895, com base em autorizaçáo dada pelo decreto de criação do próprio tribunal. Concebido para vigorar até que a matéria viesse a ser regulada por lei, o RCPM vigeria até 1920.

Vinte e cinco anos de funcionamento ilegal, diria Rui Barbosa ainda em 1905, quando defendia acusados de participaçáo na Revolta da Vacina, ocorrida no Rio de Janeiro no ano anterior:

A Constituição declarou que o direito processual é assunto legislativo, a Constituição o encarregou ao Congresso. Entretanto, o regulamento de 16 de julho de 1895 abrange o direito processual militar no seu todo, organizando os tribunais, criando a polícia judicial, precisando as competências, dando a forma ao processo, fixando os casos de prisão, instituindo as condições das sentenças, taxando-lhes os recursos, e pautando-lhes a execução. É, portanto, indubitavelmente, sob o falso nome de regulamento, a lei do processo criminal, para as forças de mar e terra. Logo, só o Congresso a podia fazer. Logo, não a podia fazer um tribunal. Logo, feita pelo Supremo Tribunal Militar, é vã, írrita, nenhuma: não vale, não obriga, não existe. (...) Logo, os juízes, que funcionam hoje no foro militar, não são juizes. Logo, os processos, que hoje correm pela justiça militar, não são processos. Logo, as sentenças, que ora se pronunciam nos tribunais militares, não são sentenças. Os réus do conflito de 14 de novembro, por consequência, não estão sendo julgados. Vexados, sim, coagidos, tiranizados ${ }^{56}$.

A acusação do veterano liberal, abstraída a sua adesão à mitologia jurídica que envolve a ideia de julgamento, traduzia uma tendência que acabaria por se concretizar, com picos de incidência durante as ditaduras pós-1930: o envolvimento da Justiça Militar por uma trama de articulaçóes políticas que a instrumentaliza. Ainda assim, não há por que concordar com Rui totalmente. Mesmo nessas circunstâncias, há juízes, há processos, há sentenças, há julgamento, sim. O que muda é o papel do mecanismo judiciário nas relações de poder.

\footnotetext{
${ }^{54}$ Ibidem, p. 43.

${ }^{55}$ Ibidem, p. 40.

${ }^{56}$ Senado Federal, sessão em 5 de agosto de 1905. Transcrito em: FUNDAÇÃO CASA DE RUI BARBOSA (Org.; sel.). Pensamento e ação de Rui Barbosa. Brasília (DF): Fundação Casa de Rui Barbosa; Senado Federal, 1999. p. 267. Grifos meus.
} 